\title{
PENGARUH PEMBERIAN MAKANAN TAMBAHAN TERHADAP KONSUMSI ENERGI DAN PROTEIN IBU HAMIL
}

\author{
(The Effect of Food Suplement on Energy and Protein Consumption of Pregnant Mothers)
}

V. Prihananto ${ }^{1}$, Ahmad Sulaeman ${ }^{2}$, Hadi Riyadi ${ }^{2}$ dan Nur Heni Sri Palupi ${ }^{3}$

\begin{abstract}
ABST RACT
The objective of this study was to analyze the effect of supplementary foods on pregnant mothers' energy and protein consumtion. This study was conducted in three subdistricts i.e.: Leuwiliang, Leuwisadeng and Ciampea. The 140 pregnant mothers from these sub-districts were selected for this study. Out of 140 pregnant mothers, 70 pregnant mothers were selected to receive supplementary foods for 6 month and 70 pregnant mothers did not receive any experimental food (control). Product selected as intervention consists of vermicelli, milk, and biscuit. The results of the study showed intervention could improve energy protein consumption of pregnant mothers
\end{abstract}

Keywords: pregnant mothers, energy protein

\section{PENDAHULUAN}

\section{Latar Belakang}

Penanggulangan masalah gizi dan kesehatan untuk meningkatkan kualitas sumberdaya manusia, paling tepat dilakukan pada masa menjelang dan saat prenatal. Alasan yang mendukung hal tersebut adalah : (1) perkembangan otak dimulai pada masa kehamilan, (2) ibu hamil yang menderita defisiensi zat gizi mempunyai risiko lebih besar untuk memiliki bayi dengan berat badan lahir rendah (BBLR), (3) bayi BBLR mempunyai risiko lebih besar untuk meninggal pada usia satu tahun, dan jika mampu bertahan hidup akan mempunyai risiko lebih besar untuk menderita penyakit degeneratif pada usia yang lebih muda dibandingkan bayi yang lahir dengan berat normal (Barker, Osmond, \& Wield, 1993). Berat badan bayi lahir rendah juga dapat menyebabkan kekerdilan bila kondisi kesehatan dan makanan tidak cukup selama perkembangan setelah kelahiran. Kondisi tersebut merupakan penyebab lebih dari 50\%anak-anak di Asia Selatan memiliki berat badan rendah (Allen \& Gillespie, 2001). Dampak BBLR yang lebih luas pada anak yaitu menurunkan kecerdasan, mengganggu pertumbuhan, imunitas rendah dan morbiditas meningkat, mortalitas

\footnotetext{
${ }^{1}$ Staf Pengajar J urusan Teknologi Hasil Pertanian, Fakultas Pertanian, UNSOED.

2 Staf Pengajar Departemen Gizi Masyarakat, Fakultas Ekologi Manusia (FEMA), IPB

${ }^{3}$ Staf Pengajar Departemen IImu dan Teknologi Pangan, Fakultas Teknologi Pertanian (FATETA), IPB
}

meningkat, serta munculnya berbagai penyakit degeneratif saat dewasa (Depkes, 2003).

Selain BBLR, dampak dari kurang gizi saat hamil adalah risiko terjadinya angka kematian ibu (AKI) hamil yang lebih besar. Asian Development Bank (2004), melaporkan AKI di Indonesia masih cukup tinggi, yaitu 307 per 100000 kelahiran.

Masalah gizi pada ibu hamil yang paling umum yaitu kurang energi protein, vitamin $A$ dan anemi gizi. Di negara berkembang prevalensi anemi antara 35 - 75\% dan di negara maju sekitar 18\% (WHO, 1992). Di Indonesia, tahun 2001 prevalensi anemi ibu hamil 40\% dan kurang energi kronis 41\% (Depkes, 2003). Di negara berkembang rata-rata konsumsi energi hanya dua per tiga dari rekomendasi yang dianjurkan (Mora \& Nestel, 2000). Penelitian Effendi et al. (1998) di Kecamatan Leuwiliang, Kabupaten Bogor menunjukkan sekitar 60\% ibu hamil menderita defisiensi vitamin A (kadar vitamin A plasma $3.1 \mu \mathrm{g}$ retinol/ $\mathrm{dl}$ ).

Masalah anemi di Indonesia yang paling umum adalah anemi gizi besi. Hal ini disebabkan oleh berbagai faktor yaitu makanan yang dikonsumsi kurang mengandung zat besi terutama dalam bentuk besi-heme, tidak cukup konsumsi vitamin $C$, dan adanya gangguan absorpsi (Verst, 1996; Weigel et al., 1992), defisiensi vitamin A, vitamin B12, folat, dan seng (Broek \& Letsky, 2000).

Memperhatikan dampak kurang gizi yang sangat luas, maka diperlukan upaya penanganan gizi ibu hamil. Berkaitan dengan hal tersebut telah dilakukan intervensi pemberian makanan tambahan pada ibu hamil. 


\section{$\underline{\text { Tujuan }}$}

Tujuan penelitian ini adalah menganalisis pengaruh pemberian makanan tambahan terhadap peningkatan konsumsi energi dan protein ibu hamil.

\section{METODE PENELITIAN}

\section{Desain, Tempat dan Waktu Penelitian}

Rancangan yang digunakan pada penelitian ini berbentuk experimental. Penelitian dilakukan di wilayah Kabupaten Bogor. Penentuan lokasi kecamatan didasarkan pada pertimbangan kemudahan teknis di lapangan dan adanya kerjasama yang baik dari pihak puskesmas dan kecamatan setempat, serta didasarkan pada tujuan penelitian. Kecamatan terpilih adalah Leuwiliang, Leuwisadeng dan Ciampea. Penelitian (intervensi PMT) dilakukan selama enam bulan.

\section{Łenis dan Cara Pengumpulan Data}

Jenis data yang dikumpulkan meliputi keadaan sosial ekonomi keluarga, usia kehamilan pada awal penelitian, konsumsi pangan, dan tingkat kepatuhan konsumsi.

Contoh penelitian dan perlakuan dipilih secara acak. Pada penelitian ini ada dua kelompok: (a) perlakuan dan (c) kontrol. Jumlah contoh ibu hamil sebanyak 140 orang yang dibagi menjadi 2 kelompok. Kelompok pertama 70 orang diberikan intervensi makanan tambahan dan kelompok kedua 70 orang sebagai kontrol. Pada perkembangannya terjadi drop out masing-masing sebanyak 7 ibu hamil sehingga jumlah contoh diakhir penelitian masing-masing kelompok tinggal 63 ibu hamil.
Syarat contoh yang dipilih adalah ibu hamil usia 18 - 35 tahun, usia kehamilan 2 - 5 bulan, tidak merokok dan minum alkohol, serta tidak sakit kronik. Selain pemberian makanan tambahan, kepada kedua kelompok diberikan penyuluhan/ pendidikan gizi, termasuk di dalamnya yaitu penyuluhan tentang keamanan makanan khususnya penyiapan makanan untuk ibu hamil.

Paket produk PMT diberikan tiap minggu untuk dikonsumsi setiap hari. Jenis produk PMT meliputi susu, biskuit dengan tiga rasa dan bihun satu rasa. Tiap ibu hamil diberi satu paket produk PMT per minggu untuk dikonsumsi setiap hari. Tiap minggu, paket produk yang diberikan selalu bervariasi (Tabel 2).

\section{Pengolahan dan Analisis Data}

Pengolahan data statistik dasar yang dilakukan adalah rata-rata, simpangan baku, nilai minimum dan maksimum. Statistik dan proporsi yang dihitung disajikan dalam bentuk tabel, gambar, diagram, dan Iain-lain. Untuk melihat pengaruh intervensi pemberian makanan tambahan terhadap peningkatan konsumsi energi dan protein ibu hamil dilakukan pembandingan antara kelompok intervensi dan kontrol. Pengolahan dan analis data menggunakan komputer program SPSS 13.0 for windows.

\section{HASIL DAN PEMBAHASAN}

\section{Karakteristik Responden}

Karakteristik keluarga yang terdiri dari pendapatan keluarga, besar keluarga, lama pendidikan suami, lama pendidikan ibu hamil, usia kehamilan, umur ibu hamil dan umur

Tabel 1. Kontribusi Zat Gizi Intervensi Makanan Tambahan per Hari per Ibu Hamil

\begin{tabular}{|l|c|c|c|c|c|c|c|c|}
\hline \multicolumn{1}{|c|}{ Kelompok } & $\begin{array}{c}\text { Energi } \\
\text { (kkal) }\end{array}$ & $\begin{array}{c}\text { Protein } \\
\text { (g) }\end{array}$ & $\begin{array}{c}\text { Vit A } \\
\text { (RE) }\end{array}$ & $\begin{array}{c}\text { As folat } \\
\text { (mcg) }\end{array}$ & $\begin{array}{c}\text { Vit C } \\
\text { (mg) }\end{array}$ & $\begin{array}{c}\text { Besi } \\
\text { (mg) }\end{array}$ & $\begin{array}{c}\text { Seng } \\
\text { (mg) }\end{array}$ & $\begin{array}{c}\text { lodium } \\
\text { (mcg) }\end{array}$ \\
\hline Perlakuan & 531.3 & 14.2 & 164.3 & 34.5 & 51.5 & 2.7 & 2.0 & 23.5 \\
\hline \%AKG & 27.9 & 23.3 & 20.5 & 5.7 & 60.6 & 8.6 & 15.7 & 11.7 \\
\hline Kontrol & - & - & - & - & - & - & - & - \\
\hline
\end{tabular}

Tabel 2. Variasi Pemberian Produk Makanan Tambahan untuk Ibu Hamil

\begin{tabular}{|c|c|c|c|c|c|c|c|}
\hline \multirow{3}{*}{ Minggu } & \multicolumn{7}{|c|}{ Produk } \\
\hline & \multicolumn{3}{|c|}{ Susu Rasa } & \multicolumn{3}{|c|}{ Biskuit Rasa } & \multirow{2}{*}{ Bihun } \\
\hline & coklat & vanila & katuk & susu & coklat & keju & \\
\hline 1. & $X X$ & & & $\mathrm{XX}$ & & & \\
\hline 2. & & $X X$ & & & & & $X X$ \\
\hline 3. & & & $X X$ & & $X X$ & & \\
\hline 4. & $X X$ & & & & & & $\mathrm{XX}$ \\
\hline 5. & & $X X$ & & & & $X X$ & \\
\hline 6. & & & $\mathrm{XX}$ & & & & $X X$ \\
\hline 7. & $X X$ & & & $X X$ & & & \\
\hline
\end{tabular}


suami tidak berbeda nyata antara kelompok perlakuan dengan kelompok kontrol kecuali pendidikan ibu hamil pada $(p<0.05)$. Pendidikan ibu hamil kelompok kontrol nyata lebih tinggi dibanding kelompok perlakuan (Tabel 3).

\section{Цenis Produk}

Beberapa faktor yang dipertimbangkan dalam pemilihan jenis produk adalah produk sudah dikenal dan memiliki citarasa yang baik sehingga disukai serta diterima masyarakat secara luas, praktis, punya daya simpan relatif lama dan mudah dalam penyajiannya. Aspek lain yang dipertimbangkan adalah komposisi gizi produk. Jenis produk terpilih berupa biskuit, bihun, dan susu. Ketiganya hanya berbeda dalam hal rasa, tetapi komposisi gizinya relatif sama. Secara lengkap komposisi gizi produk disajikan pada Tabel 4.

Berdasarkan Tabel 4 nampak bahwa kandungan gizi makro (energi dan protein) biskuit dan bihun relatif lebih rendah dibandingkan susu. Oleh karena itu diperlukan adanya upaya pengembangan produk untuk meningkatkan kandungan protein tanpa banyak mengubah biaya produksi sehingga harga jual diharapkan tidak banyak berubah.

\section{Tingkat Kepatuhan Konsumsi Produk}

Pada intervensi pemberian makanan tambahan, selain kandungan gizi, faktor lain yang berpengaruh terhadap tingkat kepatuhan konsumsi harus diperhatikan. Sifat sensoris, preferensi, daya terima dan variasi produk yang diberikan adalah komponen yang mempengaruhi tingkat kepatuhan konsumsi. Variasi produk diharapkan dapat meminimalkan unsur kebosanan/kejenuhan sehingga akan meningkatkan tingkat kepatuhan konsumsi terhadap produk yang diberikan.

\section{Rata-rata Tingkat Kepatuhan}

Hasil penelitian menunjukkan rata-rata tingkat kepatuhan konsumsi produk yang diberikan cukup tinggi yaitu 93\% Tingkat kepatuhan konsumsi terhadap biskuit paling tinggi (94.0\%), kemudian diikuti susu (93.5\%) dan terakhir bihun (92.5\%)(Gambar 1 ).

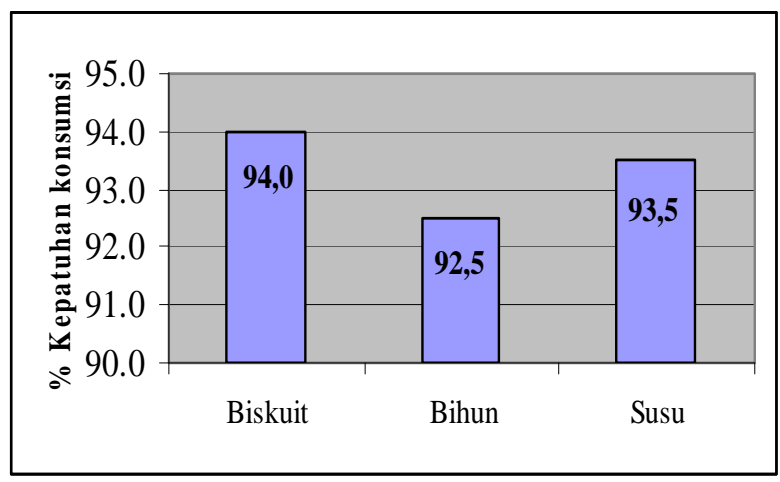

Gambar 1. Persentase Tingkat Kepatuhan terhadap Produk Intervensi

Tabel 3. Karakteristik Responden pada Berbagai Kelompok

\begin{tabular}{|l|c|c|c|}
\hline \multicolumn{1}{|c|}{ Variabel } & Perlakuan $(\mathbf{n = 6 3 )}$ & Kontrol (n=63) & Sig. \\
\hline Pendapatan keluarga (Rp) & $536274 \pm 317835$ & $573547 \pm 254035$ & 0.879 \\
\hline Besar Keluarga (org) & $4.6 \pm 1.6$ & $4.9 \pm 2.5$ & 0.159 \\
\hline Lama Pendidikan Isteri (th) & $6.5 \pm 2.2$ & $7.5 \pm 2.2$ & 0.021 \\
\hline Lama Pendidikan suami (th) & $7.6 \pm 2.6$ & $7.4 \pm 2.9$ & 0.337 \\
\hline Usia Kehamilan (bIn) & $3.40 \pm 1.0$ & $3.48 \pm 1.1$ & 0.545 \\
\hline Umur Isteri (th) & $26.9 \pm 3.9$ & $26.8 \pm 4.5$ & 0.210 \\
\hline Umur Suami (th) & $32.4 \pm 5.1$ & $32.9 \pm 7.1$ & 0.033 \\
\hline
\end{tabular}

Tabel 4. Komposisi Zat Gizi dalam 100 gram

\begin{tabular}{|l|c|c|c|}
\hline \multicolumn{1}{|c|}{ Zat Gizi } & Biskuit & Bihun & Susu \\
\hline Energi (Kkal) & 486 & 378 & 410 \\
\hline Protein (\%) & 7.0 & 5.5 & 15.3 \\
\hline Fe (mg) & 3.2 & 2.6 & 1.5 \\
\hline Iodium (mcg) & 20.9 & 2.0 & 24.6 \\
\hline Vit A (RE) & 125 & 35 & 170 \\
\hline Vit C (mg) & 1.0 & 3.4 & 71.8 \\
\hline Asam Folat (mcg) & 23.4 & 25.3 & 29.6 \\
\hline Seng (mg) & 1.6 & 0.7 & 2.0 \\
\hline Kadar Air (\%) & 2.7 & 10.2 & 1.9 \\
\hline Kadar Abu (\%) & 1.2 & 3.2 & 4.3 \\
\hline Kadar Lemak (\%) & 20.5 & 6.4 & 7.1 \\
\hline Kadar Karbohidrat (\%) & 66.1 & 74.7 & 71.4 \\
\hline
\end{tabular}


Tingginya tingkat kepatuhan konsumsi produk feeding dipengaruhi antara lain oleh variasi produk yang diberikan, sifat sensoris, dan juga keberhasilan dalam sosialisasi pada ibu hamil. Variasi produk yang diberikan meliputi susu coklat + biskuit susu, susu vanila + bihun, susu katuk + biskuit coklat, susu coklat + bihun dan susu vanila + biskuit keju. Banyaknya variasi produk yang diberikan dapat menurunkan unsur kebosanan/kejenuhan terhadap produk intervensi.

Berdasarkan Gambar 1, nampak bahwa bihun, biskuit dan susu memiliki sifat sensoris yang diterima masyarakat. Hal ini dapat dilihat dari tingkat kepatuhan konsumsi yang lebih besar dari $90 \%$ untuk ketiga produk. Selain faktor-faktor yang telah disebutkan di atas, tingginya tingkat kepatuhan konsumsi dikarenakan ketiga produk sudah sangat dikenal masyarakat. Bahan baku bihun adalah beras yang merupakan makanan pokok masyarakat Indonesia. Biskuit terbuat dari terigu dan pati garut yang telah dikonsumsi secara luas oleh masyarakat, demikian pula dengan susu merupakan minuman yang juga diterima masyarakat.

\section{Rataan Intik Zat Gizi}

\section{Pada Awal Penelitian (Sebelum Intervensi)}

Secara umum rata-rata intik zat gizi pada semua kelompok masih di bawah kebutuhan gizi yang dianjurkan menurut Widyakarya Nasional Pangan dan Gizi tahun 2004. Ratarata konsumsi energi pada kelompok kontrol $1412 \mathrm{kkal}$ (76.4\% AKG) dan kelompok perlakuan 1265 kkal ( 67.1\%AKG) (Tabel 5). Seca- ra statistik, rata-rata konsumsi zat gizi antara perlakuan dan kontrol tidak berbeda nyata pada $\alpha=0.05$.

Uraian di atas menunjukkan bahwa ibu hamil pada kelompok kontrol dan perlakuan, mengalami defisit energi berat yaitu konsumsi energi $<70 \%$ dari rekomendasi yang dianjurkan (Tabel 6).

Berdasarkan Tabel 6, terlihat sebanyak $50.6 \%$ ibu hamil yang mengalami defisit tingkat kecukupan energi berat. Tingkat defisit kecukupan energi antara kelompok perlakuan dan kontrol relatif homogen. Pada kelompok perlakuan $53.5 \%$ dan kontrol $43.1 \%$ Kenyataan tersebut memberikan jastifikasi pada wilayah tersebut pentingnya dilakukan intervensi gizi pada ibu hamil terutama dalam rangka peningkatan dan perbaikan konsumsi zat gizi makro (energi dan protein).

Faktor dominan rendahnya tingkat konsumsi zat gizi diduga ada dua hal yaitu (a) status sosial ekonomi yang rendah yang berimplikasi pada daya beli rendah dan (b) adanya penurunan nafsu makan pada periode awal kehamilan. Hal ini dapat terjadi karena pada trimester pertama kehamilan akan terjadi peningkatan metabolisme, perubahan hormonal dan juga sistem organ mulai dibentuk dan mulai berfungsi. Bagi ibu hamil periode ini merupakan masa penyesuaian baik secara fisik, maupun emosi. Ibu hamil umumnya akan mengalami perasaan ingin muntah, mual, merasa lelah yang dikenal dengan morning sickness, walaupun kejadian ini dapat terjadi tidak hanya di pagi hari.

Tabel 5. Sebaran Ibu Hamil berdasarkan Rata-rata Konsumsi Zat Gizi

\begin{tabular}{|l|r|r|l|l|}
\hline Konsumsi gizi & Perlakuan & Kontrol & AKG Energi & AKG Protein \\
\hline Energi (kkal) & 1266 & 1412 & & \\
\cline { 1 - 3 } Protein (gr) & 27.6 & 30.0 & \multirow{2}{*}{ Perlakuan $=1886 \mathrm{kkal}$} & Perlakuan $=62.0 \mathrm{~g}$ \\
\hline Vitamin A (RE) & 499 & 618 & \multirow{2}{*}{ Kontrol $=1849 \mathrm{kkal}$} & \multirow{2}{*}{ Kontrol $=60.5 \mathrm{~g}$} \\
\hline Vitamin C (mg) & 26.7 & 23.8 & & \\
\cline { 1 - 3 } Karbohidrat (gr) & 221.6 & 280.5 & & \\
\hline Lemak (gr) & 31.0 & 33.1 & & \\
\hline Fe (mg) & 10.3 & 10.5 & & \\
\hline
\end{tabular}

Tabel 6. Sebaran Ibu Hamil berdasarkan Tingkat Kecukupan Energi

\begin{tabular}{|l|c|c|c|}
\hline \multicolumn{1}{|c|}{ Kriteria } & Kategori TKE* & Kontrol (\%) & Perlakuan (\%) \\
\hline Defisit Tingkat Berat & $<70 \%$ & 43.1 & 53.5 \\
\hline Defisit Tingkat Sedang & $70-79 \%$ & 15.5 & 17.2 \\
\hline Defisit Tingkat Ringan & $80-89 \%$ & 13.8 & 8.6 \\
\hline Normal & $90-120 \%$ & 17.2 & 17.2 \\
\hline Berlebih & $>120 \%$ & 10.3 & 3.5 \\
\hline J umlah & & 100 & 100 \\
\hline
\end{tabular}

*) TKE= Tingkat Kecukupan Energi 
Besaran defisit tingkat kecukupan energi di wilayah penelitian ternyata melebihi kondisi di tahun 1998, dimana konsumsi energi kurang dari $70 \%$ sebesar $48 \%$ (Depkes, 2003). Keadaan ini terjadi di kebanyakan negara berkembang. Mora dan Nestel (2000) melaporkan rataan tingkat konsumsi energi di negara berkembang hanya sebesar dua per tiga dari rekomendasi yang dianjurkan.

\section{Akhir Intervensi}

Tingkat konsumsi energi dan protein pada akhir intervensi berbeda nyata antara kelompok perlakuan dan kontrol $(p<0.05)$. Hal ini berarti intervensi pangan dapat meningkatkan konsumsi energi dan protein. Pada Tabel 7 ditunjukkan bahwa konsumsi energi kelompok perlakuan 1993 kkal, lebih besar dibandingkan kelompok kontrol (1809 kkal). Hal yang sama terjadi pada konsumsi protein. Konsumsi protein kelompok perlakuan $46.6 \mathrm{~g}$, lebih besar dibanding kontrol (40.2 g).

Tabel 7. Konsumsi Zat Gizi pada Awal dan Akhir Kehamilan

\begin{tabular}{|l|c|c|c|c|c|c|}
\hline \multirow{2}{*}{$\begin{array}{c}\text { Konsumsi } \\
\text { gizi }\end{array}$} & \multicolumn{3}{|c|}{ Perlakuan } & \multicolumn{3}{c|}{ Kontrol } \\
\cline { 2 - 7 } & Awal & Akhir & Selisih & Awal & Akhir & Selisih \\
\hline $\begin{array}{l}\text { Energi } \\
\text { (kkal) }\end{array}$ & 1266 & $1993 \mathrm{a}$ & 727 & 1413 & $1809 \mathrm{~b}$ & 396 \\
\hline $\begin{array}{l}\text { Protein } \\
\text { (gr) }\end{array}$ & 27.6 & $46.6 \mathrm{a}$ & 19.1 & 30.0 & $40.2 \mathrm{~b}$ & 10.2 \\
\hline
\end{tabular}

Keterangan: Nilai yang diikuti huruf yang berbeda pada baris yang sama menunjukkan beda.

Berdasarkan Tabel 7 nampak bahwa konsumsi energi kelompok perlakuan telah melampui tingkat kecukupan gizi yang dianjurkan. Tingkat kecukupan energi sebesar 102\% AKG. Berbeda halnya dengan konsumsi protein, intervensi pangan ternyata belum mampu memenuhi tingkat kecukupan protein. Tingkat konsumsi protein kelompok perlakuan sebesar $46.6 \mathrm{~g}(76.6 \% \mathrm{AKG})$. Bila dibandingkan dengan kontrol konsumsi energi maupun protein pada kelompok perlakuan lebih tinggi.

Berdasarkan fakta tersebut dapat ditarik suatu kesimpulan: (a). Persen AKG protein perlu ditingkatkan dalam melakukan intervensi pemberian makanan tambahan pada ibu hamil dan (b). Kandungan protein pada biskuit dan bihun masih perlu dikaji untuk dapat ditingkatkan tanpa banyak mengubah biaya produksi dan juga sifat sensoris dari produk tetap dapat diterima dan disukai oleh ibu hamil.

\section{KESIMPULAN DAN SARAN}

\section{Kesimpulan}

1. Tingkat kepatuhan konsumsi produk cukup tinggi berturut-turut: bihun $92.5 \%$ biskuit $94.0 \%$ dan susu $93.5 \%$

2. Intervensi makanan tambahan denganenergi $27.9 \%$ AKG dan protein $23.3 \%$ AKG dapat memenuhi tingkat kecukupan energi ibu hamil sebesar 102\% AKG, sedangkan protein baru terpenuhi 76.6\%AKG.

\section{Saran}

1. Perlu adanya upaya pengembangan produk biskuit dan bihun untuk meningkatkan kandungan proteinnya.

2. Perlu adanya kajian intervensi makanan tambahan pada ibu hamil dengan \% AKG protein lebih tinggi dari 23.3\%AKG.

\section{UCAPAN TERIMA KASIH}

kepada:

Penulis mengucapkan terima kasih

a. SEAFAST CENTER Institut Pertanian Bogor (IPB) yang telah memberikan dana penelitian.

b. Tim Feeding Program dari Departemen Ilmu dan Teknologi Pangan dan Gizi Masyarakat IPB yang telah memberikan kesempatan bergabung untuk melaksanakan penelitian hingga penelitian selesai.

\section{DAFTAR PUSTAKA}

Allen \& Gillespie. 2001. What works? A review of the efficacy and effectiveness of nutrition interventions. ACC/SCN Nutrition Policy Paper no. 19 - ADB Nutrition and Development Series No. 5.

Barker DJ , Osmonds PC \& Wield GA. 1993. The relation of small head circumstance and thinness at birth to death from cardiovascular disease in adult life. Brit Med J, 306.

Departemen Kesehatan RI. 2003. Gizi dalam Angka. Depkes RI, J akarta.

Effendi YH, Hardinsyah, Briawan D, \& Alsuhendra. 1998. Analisis Zat Gizi dan Profil Lipid Serum Darah serta Kebiasaan Makan Ibu Hamil di Kecamatan Leuwiliang, Kabupaten Bogor. Laporan 
Penelitian Jurusan Gizi Masyarakat dan Sumberdaya Keluarga, Fakultas Pertanian, IPB, Bogor.

Mora OJ \& Nestel P. 2000. Improving prenatal nutrition in developing countries: Strategies, prospects, and challenge. American Journal of Clinical Nutrition, 71(5), 1353S-1363S

Broek V \& Letsky. 2000. Etiology of anemia in pregnancy in South Malawi. Am J Clin Nutr, 72, 247S-256S.

Verst A. 1996. Fortification of Flour with Iron in Countries of the Eastern Mediterran- ean Middle East And North Africa. Regional Adviser, Nutrition, Food security and Safety, WHO, Regional Office for The eastern Mediterranean.

World Health Organization (WHO). 1992. The Prevalence of Anemia in Women: A tabulation of available information 2nd ed. Geneva.

Weigel MM et al. 1992. Nutritional and health status of rural women colonists in the subtropical lowlands of northwest Ecuador. Ecology of Food and Nutrition 29(1), 24-43 (Abs, CD Rom). 